\title{
Pengaruh Perubahan Kadar Air pada Sifat-Sifat Tanah Organik yang distabilisasi dengan Limbah Karbit dan Abu Ampas Tebu
}

\author{
John Tri HATMOKO ${ }^{1 *} \cdot$ Luky HANDOKO $^{2}$ \\ ${ }^{1}$ Program Studi Teknik Sipil Universitas Atma Jaya Yogyakarta, email: john@staff.uajy.ac.id \\ ${ }^{2}$ Program Studi Teknik Sipil Universitas Atma Jaya Yogyakarta, email: luky.handoko@uajy.ac.id
}

\begin{abstract}
Research on organic soil stabilization utilizing materials such as cement, lime, rice husk ash, fly ash, bagasse ash to change soil shear behavior has been widely carried out to this date. However, not many researchers have studied the changes in water content in organic soils that have been stabilized with such materials, especially on the changes in soil physical properties. This study aims to find out the effect of changes in water content in physical properties including: volume weight $(\gamma)$, specific gravity $(G)$, water content $(w)$, void ratio (e), degree of acidity $(\mathrm{pH})$ and content organic $(O)$. A series of tests was conducted, namely the chemical composition of: organic soil test (TO), carbide waste (CCR), and bagasse ash (AAT), and testing for the physical properties of organic soil. Further, additional material (60\% CCR and 40\% AAT) was added to the soil in proportions: $5,10,15,20,25$ and 30\% combined with different initial water contents (498, 548 and 598\%) and curing time: 7, 14, 21 and 36 days. Then, we conducted test for physical properties of the soil that has been stabilized. The physical and chemical properties of the soil change subject to added material content and ripening time. At high water content, the change is more significant than at lower water content. The volume weight, specific gravity, and acidity of the soil increases while the void ratio and soil organic content decrease. The optimal content of added material is $20 \%$ with an optimal time of curing 21 days
\end{abstract}

Keywords: organic soil, bagasse ash, carbide waste, water content, physical properties, chemical properties

\section{Pendahuluan}

Tanah organik dijumpai di banyak daerah di Indonesia. Tanah ini terbentuk oleh pelapukan akar-akar tumbuhan yang pada umumnya terletak pada bagian permukaan Namun demikian di beberapa daerah, tanah organik tersebut berada sampai kedalaman yang cukup lebih dari 1 meter . Tanah organik memiliki kuat geser dan daya dukung rendah, kompresibilitas tinggi, dan kuat geser rendah. Oleh sebab itu jika tanah organik digunakan sebagai bahan konstruksi misal sebagai tanah dasar pondasi atau tanah dasar jalan raya, akan menimbulkan masalah. Sebagai contoh, jika digunakan sebagai sebagai tanah dasar pondasi, bangunan akan mengalami penurunan besar bahkan keruntuhan. Didalam praktek yang selama ini dilakukan adalah lapisan tanah organik tersebut dibuang digantikan dengan tanah yang lebih baik seperti pasir, kerikil atau bahkan dengan batu pecah yang dikenal dengan istilah potong dan ganti . Namun demikian sering kali bahan-bahan pengganti berada jauh dari lokasi proyek yang berakibat pada mahalnya konstruksi. Oleh sebab itu akan lebih baik tanah organik tersebut diperbaiki. Beberapa usaha perbaikan tanah organik dengan pengikat seperti semen, kapur, dan abu terbang dapat dilakukan dengan cepat dan dengan biaya rendah, oleh sebab itu

*penulis korespondensi 
stabilisasi kimia untuk perbaikan tanah tersebut menjadi alternatif yang cukup penting (Keshawarz, 1993; Sridharant, et.al., 1997; Kaniraj \& Havanagi, 1999; Parsons, 2005).

Abu terbang telah terbukti efektif untuk stabilisasi tanah lempung ( Ferguson, 1993; Acosta, et.al., 2003; Prabakar et.al., 2004; Bin-Shafique et.al., 2004 ; Trzebiatowski et.al., 2005), namun sedikit penelitian yang mengkaji stabilisasi tanah organik dengan abu terbang. Tanah organik lebih sulit distabilisasi secara kimia di banding dengan tanah an-organik ( Hampton and Edil 1998; Janz and Johansson 2002), Sebab tanah organik tidak memiliki kandungan mineral yang cukup dan ber $\mathrm{pH}$ rendah. Abu terbang yang merupakan limbah, keberadaannya akan semakin menipis, oleh sebab itu perlu dicari bahan tambah lain yang memiliki sifat-sifat kimia mirip dengan abu terbang. Bahan tersebut adalah abu ampas tebu.

Abu ampas tebu (AAT) adalah limbah pabrik Gula yang merupakan sisa pembakaran tetes tebu yang selama ini tidak dimanfaatkan, jika dibiarkan akan memambah pencemaran lingkungan. AAT sebenarnya mengandung unsur-unsur silika ( $\mathrm{SiO} 2)$, alumina (A12O3), dan ferrit (Fe2O3) yang cukup tinggi jika dibakar pada suhu tertentu, sehingga dapat dimanfaatkan sebagai bahan stabilisasi tanah. Limbah karbit juga merupakan limbah yang mengandung $\mathrm{CaO}$, maupun $\mathrm{Ca}(\mathrm{OH}) 2$, yang jika dikombinasikan dengan AAT akan membentuk kalsium silikat hidrat $(\mathrm{C}-\mathrm{S}-\mathrm{H})$, aluminum silikat hidrat $(\mathrm{C}-\mathrm{A}-\mathrm{H})$ maupun kalsium silikat aluminat hidrat (C-S-A-H) yang mengakibatkan kuat tekan dan perilaku geser tanah organik akan berubah. Penerapan stabilisasi tanah dengan kapur semen, abu ampas tebu, abu terbang, abu sekam padi, kombinasi abu terbang + semen, abu ampas tebu + kapur utuk tanah anorganik, lempung misalnya, sudah banyak dilakukan. (Hatmoko, 2004, 2005, 2013; Diana, W: 2012, 2013; Tahllib 2011; Yadu, L 2011; Correia, et.a., 2013).

Perilaku geser tanah organik yang distabilisasi dengan abu sekam padi (RHA) dikombinasikan dengan kapur, kombinasi RHA dengan semen sudah banyak dilakukan terutama mengenai sifat-sifat mekanikanya seperti : kuat tekan bebas, kuat geser, CBR. Perubahan perilaku mekanik tanah organik tidak dapat dipisahkan dengan perubahan sifatsifat fisik tanah seperti : kadar air (w), berat volume $(\gamma)$, berat jenis $(\mathrm{G})$, angka pori ( e ), kandungan organik $(\mathrm{O})$ dan derajat keasaman tanah $(\mathrm{pH})$. Namun demikian didalam kenyataannya di lapangan, perubahan kadar air pada tanah organik begitu besar oleh karena volume pori tanah tersebut yang cukup besar. Oleh sebab itu, penelitian ini bertujuan mengkaji perubahan sifat-sifat fisika dan kimia tanah organik yang distabilisasi dengan limbah karbit + abu ampas tebu oleh pengaruh perubahan kadar air tanah.

\section{Tinjauan Pustaka}

Tanah organik maupun tanah anorganik terbentuk secara langsung oleh proses pelapukan fisika maupun kimia dari batuan asalnya. Struktur tanah organik terbentuk dari campuran antara bahan organik dan mineral, sementara itu tanah anorganik atau yang sering disebut dengan tanah mineral terbentuk dari pelapukan batuan sehingga tanah ini mengandung mineral seperti halnya pada bautan asalnya.Tanah organik pada umumnya berwarna hitam dan merupakan pembentuk utama lahan gambut yang dalam jangka panjang akan berubah benjadi batu bara ( coal ). Tanah organik memiliki $\mathrm{pH}$ rendah, bersifat asam, disebabkan tanah organik mengandung beberapa asam organik yang merupakan hasil dekomposisi, substansi humik, dan hasil dekomposisi dari berbagai bahan organik. Disamping itu, tanah organik biasanya miskin mineral, pasokan mineral biasanya datang dari aliran air atau hasil dekomposisi jaringan makluk hidup. Tanah ini dapat ditanami tumbuhan karena bersifat gembur (berongga ) sihingga mampu menyimpan air dalam jumlah yang tinggi. Oleh sebab itu, perbaikan kimia tanah organik berbeda dengan pada tanah an-organik. 
Untuk tanah organik, reaksi posolanik yang biasanya terjadi pada tanah lempung tertunda oleh adanya kandungan organik dan rendahnya derajat keasaman $(\mathrm{pH})$ tanah (Hampton and Edil, 1998). Mekanisme terjadinya reaksi pozolanik pada tanah organik belum diketahui dengan pasti, namun demikian mekanisme tersebut pernah diusulkan oleh (Hampton and Edil, 1998; Janz and Johansson, 2002; Olivera, et.al. 2014). Reaksi posolanik/sementasi tidak terjadi antara bahan tambah dengan unsur-unsur didalam tanah, melainkan terjadi antara bahan-bahan tambah yang digunakan, misalnya antara abu terbang yang mengandung silika (SiO2) tinggi dengan kapur yang mengandung kalsium tinggi $(\mathrm{CaO})$. Reaksi sementasi antara abu terbang dengan kapur akan membentuk kalsium silikat hidrat, $\mathrm{CaSiO} 3$ atau $\mathrm{Ca} 2 \mathrm{SiO} 5$ yang berbentuk gel. Gel-gel tersebut akan mengisi rongga-rongga ataupun membungkus serat-serat organik yang berakibat pada perbaikan sifat-sifat fisika maupun mekanika tanah organik. Bahan tambah yang digunakan di dalam penelitian ini adalah kombinasi antara limbah karbit dan abu ampas tebu.

Limbah karbit atau Calcium Carbide Organike (CCR) adalah bahan sisa/limbah yang berasal dari industri pengolahan gas aseteline. Kalsium karbit ( $\mathrm{Ca} \mathrm{C} 2$ ) diperoleh dari reaksi kimia antara limbah karbit dari proses pembakaran batu limbah karbit dan arang batu. Limbah karbit ( $\mathrm{CaC} 2)$ bereaksi dengan air (H2O) membentuk gas asetiline (C2H2), Reaksi pembentukan CCR dapat dilihat pada hasil penelitian (Jaturapitakul \& Roongreung, 2003; Makaratat , 2010; Somma, 2011; Kampala \& Horpibulsuk, 2013; Horpibulsuk, 2012) : Ca C2 $+\mathrm{H} 2 \mathrm{O} \mathrm{C} 2 \mathrm{H} 2+\mathrm{Ca}(\mathrm{OH}) 2$. Abu ampas tebu adalah bahan limbah yang berasal dari penggilingan di pabrik gula. Ampas tebu yang berasal dari proses penggilingan tersebut dikeringkan, setelah kering digunakan untuk membakar tetes tebu. Abu yang berasal dari pembakaran tersebut dibuang dan menjadi limbah. Abu ampas tebu ini memiliki proporsi kandungan $\mathrm{SiO} 2$ rendah 16,03\%, namun setelah dibakar sampai dengan suhu $300 \mathrm{O}$ C dalam waktu 2 jam kadar SiO2 meningkat menjadi 62,75\% ( Wibowo \& Hatmoko 2001). Namun demikian, jika abu ampas tebu tersebut dibakar sampai dengan suhu 500OC selama 25 menit kandungan silikat ( $\mathrm{SiO} 2)+$ aluminat (A12O3) + ferat (Fe2O3) menjadi 85,21\% . Abu tersebut digunakan untuk bahan tambah beton, dan meningkatkan kuat desak sebesar 16,16\% sampai dengan $23,01 \%$. Penggunaan CCR dan abu sekam padi meningkatkan kuat tekan bebas dan kuat tarik belah secara signifikans ( Diana, W., dkk. 2012, 2013).

\section{Metodologi}

Prosedur dan alur penelitian ini dapat dilihat pada Gambar 1. Bahan adalah : tanah organik, abu apas tebu, dan limbah karbit sebagai sumber $\mathrm{CaO}$ dan juga pengikat. Tanah organik diambil dari lokasi setempat yang kemudian diuji sifat-sftat fisika ( kadar air, berat volume, berat jenis dan angka pori) serta sifat-sifat kimia ( $\mathrm{pH}$, kandungan organik). Pengujian batasbatas konsistensi mungkin juga dilakukan pada tanah organik. Abu ampas tebu (AAT) diambil dari Pabrik Gula Madukismo, kemudian dibakar sampai suhu $1000 \mathrm{C}$ untuk mengurangi hilang pijarnya (LOI). Kemudian abu ampas tebu tersebut diuji komposisi kimianya. Limbah karbit diambil dari sisa pembakaran gas acetyline setempat yang kemudian diuji komposis kimianya. Diharapkan bahwa limbah karbit tersebut memiliki kandungan kalsium $(\mathrm{CaO})$ tinggi untuk terjadinya reaksi sementasi jika ada unsur silika dan air. 


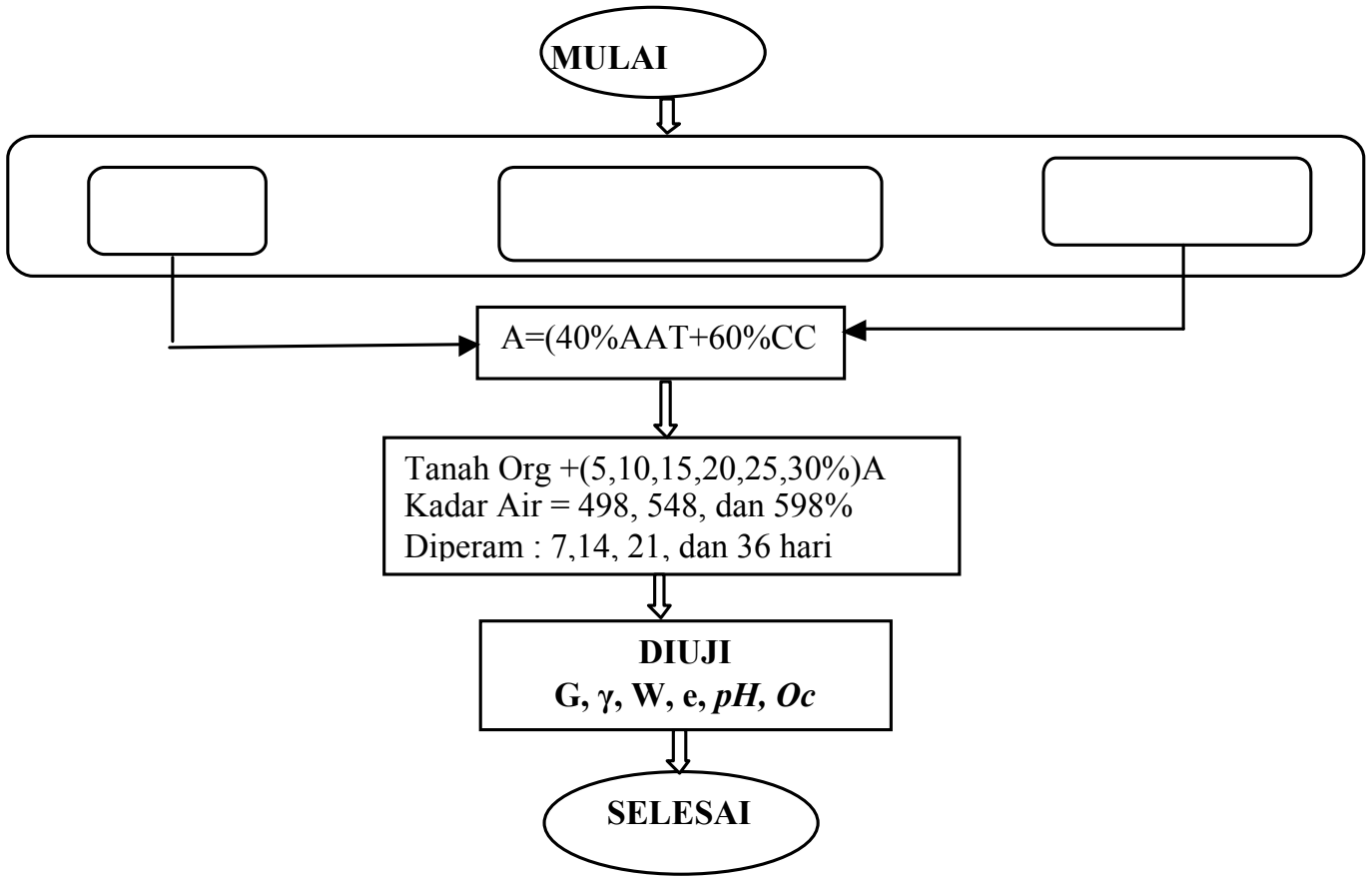

Gambar 1 Prosedur Penelitian

Pengujian-pengujian yang dilakukan adalah : kimia dan mineral tanah, kimia AAT, analisis sarungan dan hidrometer, pengujian indeks properties, pengujian pemadatan standar, pengujian derajat keasaman $(\mathrm{pH})$ tanah, pengujian tekan bebas. Alat pengujian sedapat mungkin menggunakan alat-alat uji yang ada d Kab. Mekanika Tanah FT.UAJY, namun jika alat yang dibutuhkan tidak tersedia di Lab tersebut, pengujian dilakukan di tempat lain. Sebagai contoh : pengujian kimia dan mineral tanah, pengujian $\mathrm{pH}$, dan pengujian kandungan organik. Pengujian kimia tanah dan AAT di lakukan di Departemen Perindustrian Jalan Kapas kota Yogyakarta, atau di Balai Kesehatan Lingkungan Bantul. Pengujian sifat-sifat fisika dan mekanikan tanah dilakukan dengan alat-alat yang tersedia dan dengan standarstandar tertentu. Pengujian Kadar air menggunakan standar SNI 1965 : 2008, atau ASTM D2216-92. Batas plastis dan indeks plastisitas tanah menggukan standar SNI 1966 : 2008, atau AASHTO T 90-000, sedangkan pengujian batas cair menggunakan standar SNI 1967 : 2008, atau AASHTO T 89 - 92. anaalisis saringan dan hydrometer menggunakan standar ASTM D 422. Pengujian pH menggunakan standar SNI 03-6787-2002 atau ASTM D4972.

Bahan tambah limbah karbit (CCR) dan abu ampas tebu (AAT) sebelum digunakan, dicampur dengan komposisi $40 \%$ AAT $+60 \%$ CCR sesuai hasil penelitian terdahulu ( Hatmoko dan Suryadharma 2011). Komposisi bahan tambah tersebut kemudian dicampurkan kedalam tanah organik dengan proporsi: $5,10,15,20,25$ dan 30\%. Diperam selama : 7, 14, 21 dan 36 hari yang kemudian diuji sifat-sifat fisika ( kadar air, berat volume, berat jenis, angka pori, $\mathrm{pH}$ dan kandungan organik) dan juga diuji kuat tekan bebas. Kadar air tanah diberikan pada : kadar air tanah asli, kadar air asil $+50 \%$, dan kadar air asli $+100 \%$, sehingga ada 3(tiga) komposisi kadar air. 


\section{Hasil dan Pembahasan}

\section{Tanah Organik}

Sampel tanah organik diambil dari Kabupaten Ketapang, Propinsi Kalimantan Barat. Tanah sampel ini sebenarnya adalah tanah gambut berserat dengan kandungan organik sangat tinggi sebesar 95\% (Tabel 1). Kadar air tanah ini cukup besar (498\%) disebabkan oleh penyerapan air oleh serat-serat tumbuhan yang ada di dalam tanah tersebut. Pengujian sifat-sifat fisika tanah sampel dilakukan di laboratorium Mekanika Tanah Universitas Atma Jaya Yogyakarta dengan standard pengujian ASTM-1984 (Peat Testing Manual) hasil dilihat pada Tabel 1.

Tabel 1. Sifat-sifat Fisika Tanah

\begin{tabular}{|c|c|c|}
\hline Parameter Tanah & Tanah Sampel & Penelitian Lain \\
\hline Berat Jenis(G) & 1,47 & $1,4-1,7$ \\
\hline Angka Pori $(\mathrm{e})$ & 7,1 & $6,89-11,09$ \\
\hline Berat Volume $(\gamma),\left(\mathrm{t} / \mathrm{m}^{3}\right)$ & 1,08 & $0,9-1,25$ \\
\hline Der. Keasaman $(\mathrm{pH})$ & 4,6 & $3-7$ \\
\hline Kadar air $(\mathrm{w}), \%$ & 498 & $450-1500$ \\
\hline Kand. Organik $(\mathrm{Oc}), \%$ & 95 & $62,5-98$ \\
\hline Kand. Serat $(\mathrm{Fc}), \%$ & 53,1 & $39,5-61,3$ \\
\hline
\end{tabular}

Hasil pengujian sifat-sifat fisik tanah gambut Ketapang ( Tabel 1)masih berada didalam rentang hasil penelitian sebelumnya ( Mochtar, NE. et al., 1999, 2001, 2002). Berdasarkan ASTM D-4427-92, tanah sampel tersebut dapat diklasifikasikan sebagai tanah gambut berserat moderate dengan derajat keasaman tinggi.

\section{Bahan Stabilisator}

Bahan stabilisator yang digunakan didalam penelitian ini adalah campuran antara limbah karbit (CCR) yang mengandung kapur $(\mathrm{CaO})$ tinggi dengan abu ampas tebu (AAT) yang mengandung unsur posolanik : $\mathrm{SiO} 2+\mathrm{Al} 2 \mathrm{O} 3+\mathrm{Fe} 2 \mathrm{O} 3=73,19 \%$ ( Tabel 2). Dengan tingginya kandungan $\mathrm{CaO}$ pada kimbah karbit (CCR) dan tingginya unsur-unsur posolanik pada abu ampas tebu (AAT) dengan keberadaan air didalam tanah akan terjadi reaksi sementasi dengan terbentuknya kalsium silikat hidrat (C-S-H), kalsium aluminat hidrat (C-A$\mathrm{H})$ maupun kalsium aluminat-silkat hidrat (C-A-S-H) yang berupa gel. Gel-gel tersebut akan mengisi ruang kosong pada tanah gambut dan membungkus serat-serat gambut sehingga sifat-sifat fisik dan mekanika tanah gambut meningkat.

Tabel 2. Hasil Pengujian Kimia

\begin{tabular}{|c|c|c|}
\hline Unsur Kimia & CCR & AAT \\
\hline $\mathrm{SiO}_{2}$ & 8,43 & $\mathbf{4 5 . 2 8}$ \\
\hline $\mathrm{Al}_{2} \mathrm{O}_{3}$ & 1,67 & $\mathbf{1 5 , 1 5}$ \\
\hline $\mathrm{Fe}_{2} \mathrm{O}_{3}$ & 0,91 & $\mathbf{1 2 , 7 6}$ \\
\hline $\mathrm{CaO}$ & $\mathbf{7 8 , 7 6}$ & 11,54 \\
\hline $\mathrm{Na}_{2} \mathrm{O}$ & 0,00 & 0,00 \\
\hline $\mathrm{K}_{2} \mathrm{O}$ & 0,67 & 0,00 \\
\hline $\mathrm{MgO}$ & 2,98 & 0,00 \\
\hline $\mathrm{MnO}$ & 0,09 & 0,00 \\
\hline $\mathrm{LOI}$ & 0,16 & 0,21 \\
\hline
\end{tabular}

\section{Kadar Air (w)}

Kadar air dibuat 3(tiga) variasi yaitu : kadar air tanah asli $(\mathrm{w}=498 \%),(\mathrm{w}+50 \%=548 \%)$, dan $(\mathrm{w}+100 \%=598 \%)$. Gambar 2 menunjukkan hasil pengujian perubahan kadar air oleh penambahan bahan tambah $(40 \% \mathrm{AAT}+60 \% \mathrm{CCR})$ dengan prosentase : 5, 10, 15, 20, 25 dan 
$30 \%$. Terhadap proporsi bahan tambah, penurunan kadar air tanah secara keseluruhan rerata $300 \%$. Sebagai contoh untuk waktu peram 36 hari, pada kadar air awal 498\%, 548\% dan $598 \%$ kadar air turun menjadi 150, 155, dan 159\% (pada kadar bahan tambah 30\%). Hal tersebut disebabkan oleh terjadinya reaksi sementasi/reaksi posolanik yang menyerap cukup banyak air, yang kemudian gel-gel tersebut mengisi pori yang ada pada tanah organik dan membungkus serat-serat gambut yang terkandung pada tanah tersebut. Namun demikian, kecenderungan penurunan kadar air terlihat mulai konstan (tidak cukup tajam) pada kadar bahan tambah $20 \%$ yang kemungkinan disebabkan oleh selesainya reaksi sementasi. Terhadap waktu pemeraman, penurunan kadar air terlihat cukup tajam sampai dengan masa peram 21 hari setelah itu terlihat konstan. Kecenderungan ini berbeda dengan stabilisasi tanah lempung dengan menggunakan bahan yang sama dimana semakin lama waktu pemeraman reaksi posolanik terus berlangsung. Hal ini kemungkinan disebabkan oleh kandungan silika (SiO2) pada tanah lempung. Oleh kandungan silika pada tanah lempung tersebut berakibat pada berlangsungnya reaksi posolanik yang berlanjut.

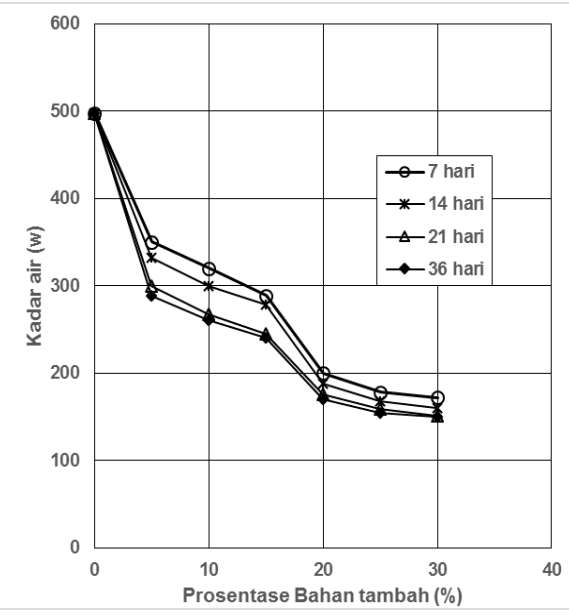

Gambar 2. Hubungan kadar air-prosen bhn tambah - masa peram ( $\mathrm{w}=498 \%$ )

\section{Berat Volume ( $\gamma)$}

Oleh penambahan bahan tambah kedalam tanah organik, berat volume tanah secara umum meningkat oleh terjadinya reaksi posolanik ( Gambar 3). Terbentuknya gel kalsium silikat hidrat maupun kalsium aluminat hidrat akan mengisi rongga-rongga tanah dan membungkus serat-serat yang berakibat pada kenaikan berat volume tanah. Terhadap prosentase bahan tambah, berat volume tanah naik secara signifikans linier terhadap proporsi bahan tambah. Namun demikian kenaikan berat volume melambat dan cenderung konstant setelah prosentase bahan tambah $20 \%$. Hal ini kemungkinan disebabkan oleh selesainya reaksi posolanik karena tidak ada cadangan silikat didalam tanah gambut organik.

Terhadap waktu pemeraman, untuk pemeraman 0 hari tidak terjadi peningkatan berat volume yang artinya volume cenderung konstan berapapun kadar bahan tambahnya. Pada 0 hari reaksi posolanik belum terjadi yang berakibat tidak adanya tambahan berat volume tanah. Semakin lama waktu pemeraman berat volume tanah semakin meningkat namun menjadi konstan setelah pemeraman 21 hari. Oleh peningkatan kadar air tanah, berat volume tanah semakin meningkat dikarenakan keberlangsungan reaksi sementasi memerlukan air yang cukup. Sebagain contoh, untuk kadar air awal 548\%, bahan tambah 30\% dan waktuperam 36 hari, berat volume meningkat dari 1,08 menjadi $1,46 \mathrm{gr} / \mathrm{cc}$ 


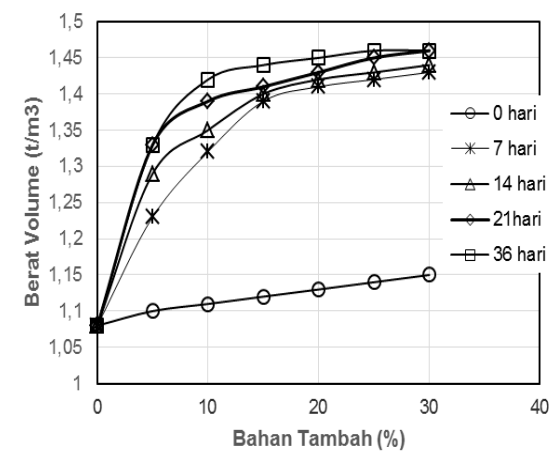

Gambar 3. Hubungan berat voulme -prosen bhn tambah - masa peram $(\mathrm{w}=548 \%)$

\section{Berat Jenis (G)}

Berat jenis tanah asli sebesar 1,47 jauh lebih rendah dibanding dengan berat jenis tanah normal (an-organik), seperti lempung yang berat jenisnya dapat mencapai harga 2,7. Dengan referensi Gambar 4, untuk masa pemeraman 0 hari dengan kadar air awal berapapun tidak menunjukkan kenaikan berat jenis tanah disebabkan belum erjadi reaksi sementasi. Hal ini berbeda dengan pada tanah lempung an-organik yang mengandung ion-ion positif bervalensi rendah seperti $\mathrm{Na}+$ dan $\mathrm{K}+$ akan digantikan oleh ion-ion positif $\mathrm{Ca}++$ dan $\mathrm{Mg}++$ yang termuat didalam limbah karbit (CCR) yang disebut dengan reaksi pertukaran ion. Reaksi tersebut terjadi dalam waktu yang sangat singkat sehingga terjadi flokulasi yang menyebabkan berat jenis meningkat. Pada masa pemeraman 7 hari untuk kadar air awal $498 \%$, berat jenis tanah meningkat menjadii 1,95 pada prosentase bahan tambah $20 \%$ yang kemudian konstan sampai dengan prosentase bahan tambah 30\%. Kecenderungan yang mirip terlihat pada tanah dengan kadar air awal 548\% dan 598\%, namun kenaikan berat jenisnya lebih tinggi . Kenaikan menjadi 2 untuk tanah dengan kadar air awal 548\% dan 2,1 untuk tanah dengan kadar air awal 598\%

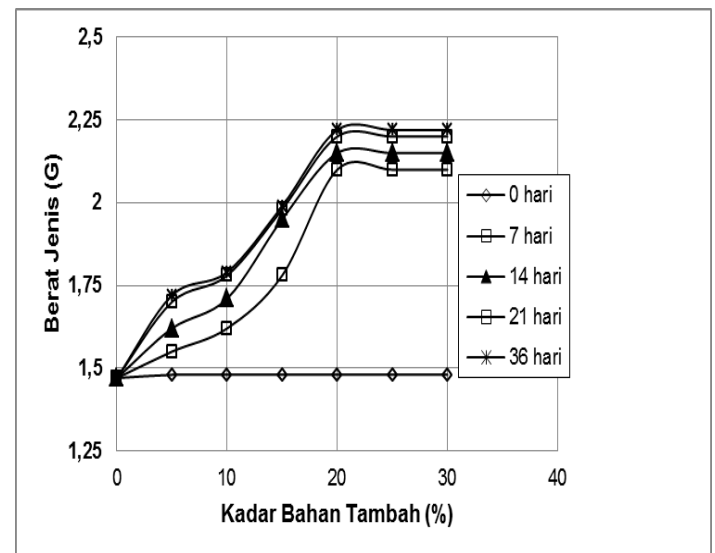

Gambar 4. Hubungan antara Berat jenis-kadar bahan tambah-waktu pemeraman $(\mathrm{w}=598 \%)$

Untuk masa pemeraman yang lain : 14, 21 dan 36 hari, kenaikan berat jenis tanah terhadap prosentase bahan tambah memiliki trend yang mirip dengan tanah yang diperam dalam waktu 7 hari. Kenaikan maksimum terjadi pada tanah yang diperam dalam waktu 36 hari namun jika dibandingkan dengan kenaikan berat jenis tanah yang diperam dengan waktu 21 hari, kenaikan tersebut tidak cukup signifikans. Hal tersebut menunjukkan bahwa reaksi sementasi selesai dalam waktu 21 hari. Pada kadar air awal tinggi, kenaikan berat jenis tanah lebih besar 
dibandingkan dengan tanah dengan kadar air awal rendah disebabkan reaksi posolanik membutuhkan air yang cukup untuk keberlangsungannya.

\section{Angka Pori (e)}

Angka pori awal ( tanah asli) sebesar 7,1 ( Tabel 1) yang berarti volume pori lebih dari 7 kali lipat volume butirannya. Rongga yang cukup besar tersebut disebabkan adanya serat-serat di dalam tanah. Gambar 5 menunjukkan perubahan angka pori oleh penambahan bahan tambah dan waktu pemeraman untuk kadar air awal 498\% dan 598\%. Pada kadar air tinggi (598\%) menunjukkan perubahan angka pori yang lebih besar di banding pada kadar air awal $498 \%$ disebabkan oleh diperlukannya air pada reaksi sementasi. Sebagai contoh, untuk ( $\mathrm{w}=598 \%$, bhn tambah $=30 \%, T=36$ hari) angka pori turun dari 7,1 menjadi 2,9.

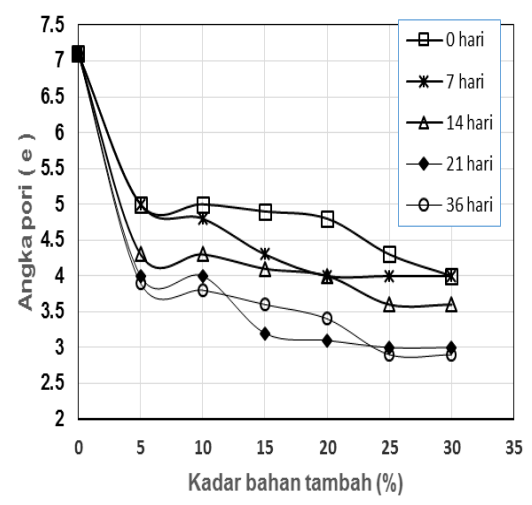

Gambar 4. Hubungan antara angka pori- prosen bhn tambah-waktu peram ( $w=598 \%)$

Dari Gambar 5 tersebut terlihat bahwa angka pori turun terhadap proporsi bahan tambah maupun oleh waktu pemeraman. Seperti halnya pada parameter fisik lainnya, angka pori turun terhadap prosentase bahan tambah sampai kadar bahan tambah $20 \%$ setelah itu kelihatan konstan. Demikian halnya terhadap waktu pemeraman. Angka pori selalu turun sampai dengan waktu pemeraman 21 hari, setelahnya penurunan melambat dan cenderung konstan. Perubahan angka pori tersebut disebabkan oleh tertutupnya pori tanah oleh gel-gel $C-S$ - $H$, $C$ - $A H$ maupun $C-S-A-H$ yang terbentuk oleh reaksi sementasi antara $C C R$ dengan abu ampas tebu (AAT). Namun demikian reaksi posolanik tersebut tidak berlangsung lama karena tidak adanya unsur-unsur silica pada tanah organic. Pada tanah lempung an-organik, reaksi posolanik dapat berlangsung cukup lama oleh adanya kandungan silica di dalam tanah lempung. Dengan jenis bahan tambah yang sama dengan pada penelitian ini, kuat geser tanah lempung yang distabilisasi dengan $C C R$ dan AAT selalu meningkat sampai usia pemeraman 56 hari (Hatmoko \& Suryadharma, 2013).

\section{Kandungan Organik (Oc)}

Penambahan bahan tambah $(60 \% \mathrm{CCR}+40 \% \mathrm{AAT})$ menyebabkan terjadinya perubahan sifatsifat fisika tanah. Kadar air (w) menurun, berat volume tanah $(\Upsilon)$ meningkat,berat jenis $(\mathrm{G})$ meningkat dan angka pori (e ) menurun. Disamping itu penambahan bahan tambah juga merubah sifat-sifat kimia tanah seperti menurunnya kandungan organik (Oc) di dalam tanah. Gambar 6 menunjukkan hubungan antara kandungan organik (Oc)-prosentase bahan tambah dan waktu pemeraman. 


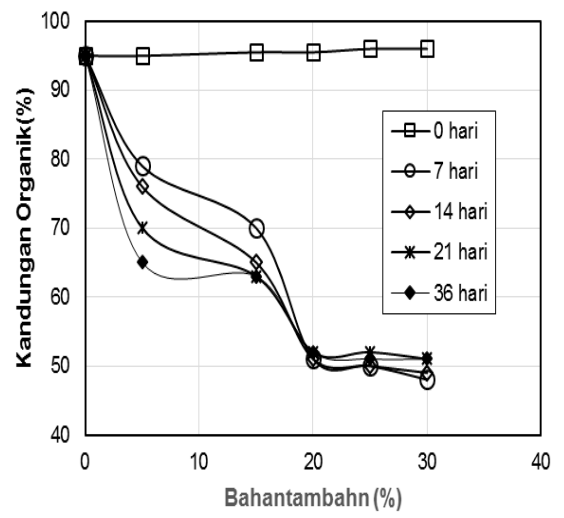

Gambar 6. Hubungan antara kand. organik-prosentase bahan tambah-waktu pemeraman $(\mathrm{w}=498 \%)$

Dari Gambar 6 tersebut, terlihat bahwa kandungan organik di dalam tanah menurun secara signifikans proporsional terhadap kandungan bahan tambah, namun pada kadar bahan tambah $>20 \%$ penurunan kandungan organik mengecil mendekati konstan. Hal ini disebabkan oleh menurunnya volume pori didalam tanah - air yang masuk kedalam tanah menurun berakibat pada terhambatnya reaksi posolanik. Terhadap waktu pemeraman, penurunan kandungan organik di dalam tanah menurun sejalan dengan bertambahnya waktu pemeraman. Semakin lama waktu pemeraman, kandungan organik semakin menurun yang menunjukkan terjadinya reaksi posolanik dimana gel-gel silikat hidrat terbentuk. Namun demikian, penurunan Oc tidak terlihat setelah masa peram 21 hari.

\section{Derajat Keasaman (pH)}

Disamping perubahan kandungan organik (Oc), perubahan kadar air dan penambahan bahan tambah meningkatkan derajat keasaman tanah organik yang distabilisasi (Gambar 7). Derajat keasaman $(\mathrm{pH})$ awal tanah sebesar 4,7 naik mendekati 7. Bahan tambah $(40 \%$ CCR + $60 \%$ AAT) yang bersifat basa menyebabkan tanah organik yang semula bersifat asam ( $\mathrm{pH}=$ 4,7) menjadi netral dengan $\mathrm{pH} 7,1$. Peningkatan keasaman tanah lebih tinggi pada kadar air awal 598\% dibanding peningkatannya pada kadar air 498\% disebabkan oleh peran air didalam pembentukan gel. Peningkatan $\mathrm{pH}$ tanah proporsional terhadap kadar bahan tambah dan waktu pemeraman.

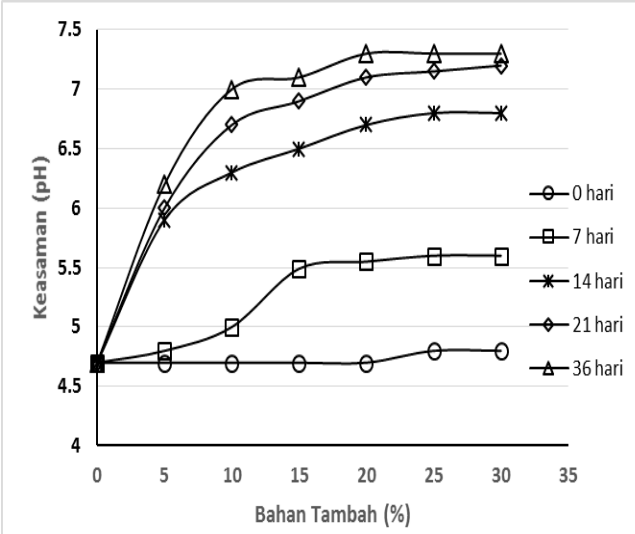

Gambar 7. Hubungan antara keasaman-prosentase bahan tambah-waktu pemeraman $(\mathrm{w}=598 \%)$ 


\section{Kesimpulan}

Dari serangkaian pengujian sifat-sifat fisika tanah organik dan pembahasan yang telah dilakukan, maka dapat ditarik kesimpulan sebagai berikut:

1. Tanah gambut Ketapang memiliki kandungan organic cukup tinggi yang dapat di kategorikan sebagai tanah organik.

2. Kadar air tanah berpengaruh besar pada perubahan sifat-sifat fisika tanah organik yang distabilisasi dengan CCR dan AAT. Pada kadar air tinggi terjadi perubahan sifat-sifat fisika tanah yang cukup signifikans dibanding pada kadar air rendah.

3. Kandungan bahan tambah (40\%AAT $+60 \%$ CCR) berpengaruh besar terhadap perubahan sifat-sifat fisika tanah. Perubahan sifat fisika tanah yang cukup signifikans terjadi sampai proporsi bahan tambah $20 \%$, setelahnya perubahan melambat dan cenderung konstan.

4. Waktu pemeraman $(7,14,21$, dan 36 hari) berpengaruh pada perubahan sifat-sifat fisika tanah. Perubahan besar terjadi sampai masa pemeraman 21 hari yang kemudian perubahan menjadi berkurang dan cenderung konstan.

5. Perubahan sifat-sifat fisika tanah yang terjadi adalah : kadar air (w) dan angka prori (e) menurun, berat volume $(\gamma)$ dan berat jenis (G) meningkat oleh gel-gel yang mengisi pori tanah dan membungkus serat-serat gambut didalam tanah.

6. Kandungan organik (Oc) tanah organic yang distabilisasi dengan limbah karbit dan abu ampas tebu menurun, sementara itu derajat keasaman tanah meningkat.

\section{Ucapan Terimakasih}

Pada kesempatan ini, penulis mengucapkan banyak terima kasih kepada Kementrian Riset Teknologi dan Pendidikan Tinggi Republik Indonesia atas pemberian dana melalui hibah Penelitian Dasar Unggulan Perguruan Tinggi (PDUPT). Ucapan terima kasih juga diucapkan kepada LPPM Universitas Atma Jaya Yogyakarta atas semua fasilitas terkait dengan publikasi ini.

\section{Daftar Pustaka}

Acosta, H.A., Edil, T.B., \& Benson, C.H. (2003). Soil stabilization and drying using fly ash" Geo Engineering Report, No. 03-03, Madison, Wiscounsin: Dept. of Civil and Environmental Engineering, University of Wiscounsin

Bin-Shafique, S., Edil, T., Benson, C., \& Senol, A. (2004). Incorporating a fly ash stabilized layer into pavement design-Case study. Proceedings of ICE Geotechnical Engineering, 157(4), 239-249

Correia, A.A.S, Venda Olivera, P.J., \& Lemons, L.J.L. (2013). Prediction of the unconfined compressive strength in soft soil chemically stabilized. Proceeding $18^{\text {th }}$ International Confrence on Soil Mechanics and Geotechnical Engineering, 2457 - 2460

Diana, W., \& Muntohar, A.S., (2012). Kuat tekan bebas tanah lempung yang distabilissi dengan limbah karbit dan abu sekam padi. Prosiding Konferensi Nasional Teknik Sipil ke 6, Universitas Trisakti Jakarta 1- 2 Nopember 2012, 33-37

Diana, W, Muntohar, A.S. (2013). Kuat geser dan kuat tarik belah tanah lempung yang distabilisasi dengan limbah karbit dan abu sekam padi. Prosiding Konferensi Nasional Teknik Sipil ke 7, Universitas Sebelas Maret, Surakarta 24 - 26 Oktober 2013, G69-75

Edil, T.B. (1997). Construction over peats and organic soils. Proceedings of conference on Recents Advances in Soft Soil Engineering, Vol. 1, Kuching, Malaysia, 85-108.

Ferguson, G. (1993). Use of self-cementing fly ashes as a soil stabilization agent. Fly ash for soil Improvement (GSP 36), ASCE New York

Hampton, M.B., \& Edil, T.B., (1998). Strength gain of organic ground with cement-type binders, Soil improvement for big digs (GSP 81), ASCE, Reston, VA, 135-148 
Hatmoko, John., T. \& Lulie, Y. (2005). UCS Tanah Lempung Ekspansif yang di stabilisasi dengan Abu Ampas Tebu dan Kapur. Laporan Penelitian Universitas Atma Jaya Yogyakarta

Horpibulsuk, S., \& Miura, N., (2001). A new approach for studying of behavior of cement stabilized clay. Proceeding the $15^{\text {th }}$ International Confrence on soil mechanics and geotechnical engineering, Vol. 3., Istanbul, Turkey, 1759-1762

Horpibulsuk, S., Phetchuay, C., \& Chinkulkijniwat, A., (2012). Soil Stabilization by Calsium Carbide Organik and Fly Ash. Journal of materials in Civil Engineering ASCE, 24(2), 184-193

Horpibulsuk. (2013). Engineering properties of silty clay stabilized with calcium carbid organic. Journal of materials in Civil Engineering ASCE, 125(5), 470 -475

Jaturapitakkul, C., \& Roongreung, B., (2003). Cementing Material from Calsium Carbide OrganikRice Husk Ash. Journal of materials in Civil Engineering ASCE, 15(5), 470-475

Janz, M., \& Johansson, SE., (2012). The function of different binding agents in deep stabilization. Sweedish Deep Stabilization Research Center Report 9, 1-35

Kampala, A., \& Horpibulsuk, S., (2013). Engineering Properties of Silty Clay Stabilized with Calcium Carbide Organike. Journal of materials in Civil Engineering ASCE, 25(5), 632-644

Kasama,K., Ochiai, H., \& Yasufuku, N. (2000). On the Stress-Strain Behavior of lightly Cemented Clay based on extended critical-state concept. Soils and Foundation, 40(5), 37-47

Kanieaj, S.R., \& Havanagi, V.G. (1999). Compressive strength of cement stabilized fly ash-soil mixtures. Cemment Conccrete Research, 29, 673-677

Keshawraz, M.S., \& Dutta, U. (1993). Stabilization of South Texas Soils with Fly Ash. Fly ash for soil improvement (GSP 36) ASCE, 30-42

Maher, M.H., \& Ho, Y.C. (1994). Mechanical Properties of kaolinite-fiber soil composite. Journal of Geotechnical Engineering ASCE. 120(8), 1381- 1393

Makarkarat, N., Jaturapitakkul, C., \& Laosamathikul, T., (2010).’Effect of Calsium Carbide Organike -Fly ash Binder on Mechanical Properties of Concrete. Journal of materials in Civil Engineering ASCE, 22(11), 1164-1170

Parsons, R.L., \& Kneebone, E (2015). Field performance of fly ash stabilized subgrades. Ground Improvement, 9(1), 33-38

Prabakar, J., Dendorkar, N., \& Morchale, R.K. (2004). Influence of fly ash on strength behavior of typical soil. Construction Building Mater, 18(4), 263-267

Somna, K., Jaturapitakkul, C., \& Kajivichyanukul, P., (2011). Microstructure of Calsium Carbide Organike-Ground Fly Ash Paste. Journal of materials in Civil Engineering ASCE, 23(3), 298-30

Sridharant, A., Prashant, J.P., \& Sivapullaiah, P.V. (1997). Effect of Fly Ash on The Unconfined Compression Strength of Black Cotton Soils. Proceeding of ICE Ground Improvement, 1(3), 169175.

Trzebiatowski, B.D., Edil, T.B., \& Bensson, C.H., (2015). Case study of subgrade stabilization using fly ash : State Highway 32, Port Wshington, Wisconsins. Recycled Materials in geotechnics (GSP 127), ASCE, Reston, VA, 123-136.

Thalib, M., \& Bankole, G.M., (2011). Improvement of index properties and compaction characteristics of lime stabilized tropical lateritic clays with risk husk admixture. Journal of Geotechnicaland Geoenvironmental Engineering, 16, 983-996

Vatsala, A, (2001). Elastoplastic Model for Cemented Soils. Journal of Geotechnical and Geoenvironmental Engineering, 127(8), 679-687

Venda Olivera, J.,P., Correia, A.S., \& Lopes, J.S. (2014). Effect of Organic Matter Content and Binder Quality on the Uniaxial Creep Behavior of an Artificially Stablized Soil. Journal of Geotechnical and Geoenvironmental Engineering, 140(9), 04014053/1-10, https://doi.org/10.1061/(ASCE)GT.1943-5606.0001158

Wibowo, F.X.N. \& Hatmoko, J.T., (2001). Pemanfaatan Abu Ampas Tebu Sebagai Bahan TambahBeton Mutu Tinggi. Laporan Studi Domestic Collaborative Research Grant (DCRG). Dir. Jin. DIKTI, DepDikBud Repulik Indonesia.

Yadu, L., Triphati, R.K., (2011). Comparison of fly ash and rice husk ash stabilized black cotton soil. International Journal of Earth Science and Engineering, 4(6), 42-45 
